\title{
MOLECULAR CHARACTERIZATION OF VIBRIO PARAHAEMOLYTICUS ISOLATED FROM SOME MOLLUSKS, SHELLFISH AND THEIR HARVESTING WATER FROM SUEZ CANAL AREA
}

\author{
YOUSSEF, A.I. ${ }^{1}$; AMANI, L.F. HEMA ${ }^{2}$ and HELAL, I.M. ${ }^{2}$ \\ ${ }^{1}$ Department of Zoonoses, Faculty of Veterinary Medicine, Suez Canal University, Round \\ Road, 4.5km, 41522, Ismailia, Egypt. \\ ${ }^{2}$ Food Hygiene Department, Animal Health Research Institute, ARC, Nadi El-Seid Street, Dokki, 12618, Giza, Egypt.
}

Received: 31 December 2017; Accepted: 31 January 2018

\begin{abstract}
The study included 410 samples of shellfish (164 clams, 86 mussels, and 160 shrimps) collected from Suez Canal area as the following: 156 from Port Said, 164 from Ismailia and 90 from Suez governorates. The harvesting water samples (48) were collected from the three sites. All samples were collected during the warmest season (June, July, and August) through two years. After extraction of muscle tissue and homogenization, enriched samples were identified by plating onto TCBS agar medium. Presumptive $V$. parahaemolyticus colonies were selected, purified, and further identified by API20 and PCR techniques targeting toxRgene. The pathogenicity of the isolates was examined by detection of Thermostable Direct Haemolysin (TDH) and related Haemolysin (TRH) genes. Results revealed that the overall prevalence of $V$. parahaemolyticus in shellfish was $38 / 410(9.27 \%)$, where as in water was $12 / 48$ (25\%). Higher contamination rate was detected in shrimp (15\%), and the highest prevalence was recorded in Ismailia governorate $(12.2 \%)$. The detection rate of TDH and TRH genes was $21.05 \%$ and $5.26 \%$ consequently indicating its health hazards to the consumers. This study concluded that the examined shellfish may have the potential human health risk associated with the presence of pathogenic V. parahaemolyticus. The preventative measures should be considered.
\end{abstract}

Key words: Vibrio parahaemolyticus, Suez Canal, Shellfish, Water, Zoonoses.

\section{INTRODUCTION}

Vibrio parahaemolyticus is a Gramnegativehalophilic and mesophilic bacterium, commonly found in estuarine environment (McCarter 1999; Su and Liu, 2007). V. parahaemolyticus is considered a natural pathogen of the aquatic environment and is also inhabited by fish, shellfish, shrimp, crayfish, oysters, and lobster and other aquatic organisms (Cook et al., 2002; Lee et al., 2008; Yamamoto et al., 2008). It has been reported that the bivalves are filter feeders which accumulate environmental bacteria in their gills and digestive glands becoming potential vectors for many pathogens including Vibrio species (Potasman et al., 2002).

Twelve Vibrio species have been recognized as potential foodborne disease agents in humans, of which, $V$. parahaemolyticus is the most common (Adams and Moss, 2008). Several Vibrio bacteria

Corresponding author: Dr. AMANI, L.F. HEMA

E-mail address:dramani_egac@yahoo.com

Present address: Food Hygiene Department, Animal Health Research Institute, ARC, Nadi El-Seid Street, Dokki, 12618, Giza, Egypt. species can cause serious disease in humans or animals. Although strains of $V$. parahaemolyticus are environmental, many strains are pathogenic to humans. Vibrio vulnificus and $V$. parahaemolyticus are the most common types of foodborne and wound infections. Virulent strains can cause wound infections, septicemia, or more commonly acute gastroenteritis which is acquired through the consumption of raw or undercooked seafood, especially shellfish.

Outbreaks of $V$. parahaemolyticus has now been detected worldwide (Nair, 2007). In Egypt, few studies on $V$. parahaemolyticus in shellfish have been conducted and almost all of them in the north of Egypt or markets that sell shellfish and oysters hunted from the Northern Egypt with an incidence ranged from 2.6 to $16.6 \%$ reached $31 \%$ (Eissa et al., 2011, Merwad et al., 2011, Abdel-Elghany and Sallam, 2013).

Not all V. parahaemolyticus strains have the same pathogenic potential. Pathogenicity is strongly correlated with two well-characterized hemolysins, the thermostable direct hemolysin (TDH) and the TDH-related hemolysin (TRH). To determine the real 
risk posed to human health by the presence of $V$. parahaemolyticus in seafood, the identification of this microorganism should be followed by the detection of the genes responsible to produce TDH and TRH toxins. The TDH and TRH genes are known to occur in $99 \%$ of clinical strains whereas; their presence in environmental strains is relatively rare (2-3\%) (Nishibuchi and Kaper, 1995). The virulence of $V$. parahaemolyticus, among other virulence attributes, depending on the presence of a thermostable direct hemolysin (TDH gene) and/or the thermostable direct hemolysin related (TRH, gene) (Ceccarelli et al., 2013; Raghunath, 2015).

Recognized infections from Vibrio species are on the rise, and although there is some uncertainty,most researchers predict that climate change will increase cases (Burge et al., 2014). Outbreaks have been reported in many countries such as the USA, France, and New Zealand because of the increase in seafood consumption and the global warming, which may be resulting in a higher prevalence of Vibrio species and increase the risk of Vibrio-borne infections (Cruz et al., 2015; Esteves et al., 2015).

The present study aimed to investigate the prevalence of $V$. parahaemolyticus in mollusks, shellfish and its harvesting water at Suez Canalarea, and to assess its pathogenicity.

\section{MATERIALS AND METHODS}

\section{Sample collection and preparation}

This study included the analysis of a total of 410 samples of wild shellfish consisted of 164 clams, 86 mussels and 160 white shrimps (Penaeuslatisulcatus). Samples were collected from the three Governorates of the Suez Canal area (Port Said, Ismailia and Suez) Governorates. Shellfish samples were collected from the Suez Canal Gulf and Suez Canal and the Mediterranean Sea that were routinely sold out at the fish market. In addition, 48 harvesting water samples were collected from the same collection areas. All samples were collected during the warmest seasons (June, July, and August) each sampling year through two years. Samples were transported with minimal delay under chilling conditions to the laboratory. Samples were analyzed and processed quickly upon arrival to the laboratory. The term sample was represented by pooled shellfish to provide $25 \mathrm{~g}$ of the soft tissue to be prepared for Vibrio isolation, one sample represented by 25 grams of the shellfish after un-shelling under sterile condition which was collected from an average from 5-10 shell fish according to the species and the size.

Isolation and biochemical identification of V.parahaemolyticus was carried out according to Kaysner and DePaola, (2004). Samples were disinfected externally before being shelled on a clean sterile surface using sterile forceps and scissors.

Fifty grams of shelled samples and $50 \mathrm{ml}$ water from water samples was placed in a stomacher bag containing $450 \mathrm{ml}$ sterile PBS (Oxoid) and mixed in a stomacher for $60 \mathrm{~s}$. This constitutes the 1:10 dilution. Prepare 1:100. 1:1000, 1:10,000 dilutions.

The homogenated samples were enriched by incubation at $35 \pm 2{ }^{\circ} \mathrm{C}$ for $24 \mathrm{~h}$. Alkaline peptone water (APW) tubes were incubated overnight at 35 $\pm 2{ }^{\circ} \mathrm{C}$. A loopful from the top $1 \mathrm{~cm}$ of APW tubes containing the three highest dilutions of sample showing growth were streakedon to plates of Thiosul fate Citrate Bile Sucrose agar (TCBS) (Oxoid) and incubated at $35 \pm 2{ }^{\circ} \mathrm{C}$ for $24 \mathrm{~h}$. Presumptive Vibrio $s p$, that appear round, opaque, green or bluish colonies, 2 to $3 \mathrm{~mm}$ in diameter on TCBS agar were selected and purified on new TCBS agar plates. Each single colony was screened for Gram staining, motility, cytochrome oxidase, urease activity, $\mathrm{NaCl}$ requirement $(0 \%, 1 \%, 3 \%, 6 \%, 8 \%$, or $10 \%)$, citrate utilization test, triple sugar iron agartest, arginine dehydrolase test, lysine and ornithine decarboxylase tests, O/129 sensitivity test, Vogese Proskauer test, indole test, Onitrophenyl-b-d- galactopyranoside (ONPG) hydrolysis and acid production from sucrose, lactose, arabinose, cellobiose, mannitol and mannose. The suspected colonies were further confirmed by both API20E test (BioMerieux, France). The reference of $V$. parahaemolyticuss trains (ATCC 17802) was used as positive control for the PCR reaction.

\section{Molecular identification of $\mathrm{V}$. parahaemolyticus and detection of TDH and TRH genes. \\ DNA extraction}

DNA extraction from enriched samples was carried out by the boilingmethod as described by Tunung et al. (2012). For the isolation of chromosomal DNA, 5 $\mathrm{ml}$ from each bacterial culture in nutrient broth (Oxoid CM0001) were incubated over night at $37^{\circ} \mathrm{C}$, followed by centrifugation at $3000 \mathrm{rpm}$ for $15 \mathrm{~min}$., the supernatant was discarded and the collected cells were suspended in $1.5 \mathrm{ml} \mathrm{TE}$ (TriseEDTA) buffer and transferred into 2 mlcentrifuge tubes and centrifuged for $1 \mathrm{~min}$ at $8000 \mathrm{rpm}$ to collect the washed cell pellet. The supernatant was then discarded and the bacterial pellet was resuspended with $500 \mathrm{ml}$ of TE and incubated at $37 \mathrm{C}$ for $2 \mathrm{~h}$ after the addition of lysozyme $(10 \mathrm{mg} / \mathrm{ml})$ and RNase $(50 \mathrm{mg} / \mathrm{ml})$. The molecular experiments were performed in the Laboratory of Zoonoses, Department of Animal Hygiene and Zoonoses, Faculty of veterinary medicine, Suez Canal University.

\section{PCR amplification reactions}


All the identified colonies as $V$. parahaemolyticus were subjected to PCR targeting species-specific gene tox Rgene to be confirmed as $V$. parahaemolyticus.

The biochemically identified $V$. parahaemolyticus isolates were further verified by molecular characterization using PCR tool for the presence of species-specific gene (tox $\mathrm{R}$ gene).

In this study, Chromosomal DNA from all the conventionally identified $V$. parahaemolyticus (n 1/4 89) was used as a template for PCR amplification using two sets of specific oligonucleotide primers for toxR gene Amplified bands of the expected molecular size of $251 \mathrm{bp}$, agarose gel electrophoresis for PCR analysis of TDH gene (A) and TRH gene (B) in $V$. parahaemolyticus isolated from different shellfish samples. Chromosomal DNA from the tox R genepositive isolates was used as a template for PCR amplification using a specific oligonucleotide primers for TDH and TRH genes.
The molecular experiments were performed in the Laboratory of Zoonoses, Department of Animal Hygiene and Zoonoses, Faculty of Veterinary Medicine, Suez Canal University, using primers sequences Forward: 5-GTCTTCTGACGCAATC GTTG-3 and Reverse: 5-ATACGAGTGGTTGCTGT CATG-3, which amplify an amplicon of 367 bp as described by Kim et al. (1999). In addition,TDH and TRH pathogenicity genes were also examined in the isolates using primers sequences as following TDH Forward: 5-CCACTACCACTCTCATATGC-3, 5GGTACTAAATGGCTGACATC-3, amplifying an amplicon size of 251bp and TRHforward: 5GGCTCAAAATGGTTAAGCG-3, REVERSE 5CATTTCCGCTCTCATATGC-3amplifying an amplicon size of $250 \mathrm{bp}$ as described by Tada et al. (1992) and sited in the following table.

The primers were ordered from Operon Company, (Operon, Japan) as nucleotide sequence. All primers were diluted according to the company instructions using sterile distilled water.

\begin{tabular}{ccccc}
\hline Target gene & Forward primers sequences & Reverse primers sequences & Amplicon size & References \\
\hline ToxR & 5-gtcttctgacgcaatcgttg-3 & 5-atacgagtggttgctgtcatg-3, & 367 & Kim et al. (1999) \\
\hline TDH & 5-ccactaccactctcatatgc-3 & 5-ggtactaaatggctgacatc-3, & 251 & $\begin{array}{c}\text { Tada } \text { et al. } \\
(1992) .\end{array}$ \\
\hline TRH & 5-ggctcaaaatggttaagcg-3, & 5-catttccgctctcatatgc-3 & 250 & $\begin{array}{c}\text { Tada } \text { et al. } \\
(1992) .\end{array}$ \\
\hline
\end{tabular}

Each PCR reaction mixture consisted of a final volume of $25 \mu \mathrm{l}$ divided to $5 \mu \mathrm{l}$ of the extracted DNA, $12.5 \mu \mathrm{l}$ of $2 \mathrm{X}$ PCR Master Mix (Biotekecorporation) [20 $\mu 1$ of Phosphate buffered saline (PBS) $\mathrm{pH}$ 7.3., Ten volumes of Tris-EDTA buffer (TE) $\mathrm{pH} 8.0,1.5$ $\mathrm{mM} \mathrm{MgCl2}, 10$ mMDeoxy Nucleotide Triphosphate solution (dNTPs) and Ampli Taq DNA polymerase (1unit/ $/ \mu \mathrm{l})$ ], $0.5 \mu \mathrm{l}$ of each primer $(5 \mathrm{pmol}$ concentration) and $6.5 \mu \mathrm{l}$ sterile distilled water. The PCR assays were performed using a Thermal Cycler (Eppendorf).

The amplification procedure consisted of an initial denaturation step at $94{ }^{\circ} \mathrm{C}$ for $2 \mathrm{~min}$, followed by 30 cycles with denaturation at $94^{\circ} \mathrm{C}$ for 30 secs, annealing for $45 \mathrm{~s}$ at $57^{\circ} \mathrm{C}$ and extension at $72{ }^{\circ} \mathrm{C}$ for 30 s. A final extension step was carried out at $72{ }^{\circ} \mathrm{C}$ for $5 \mathrm{~min}$. Aliquots from amplification reactions were analyzed by $1 \%$ agarose gel electrophoresis and viewed and photographed under UV light using gel documentation system (Biospectrum 310 imaging system). The reference of $V$. parahaemolyticus strains (ATCC 17802) was used as positive control for the PCR reaction.

\section{Statistical analysis}

Chi-square was used for calculation of significance between the prevalence at $\mathrm{P}<0.01$ using Graph Pad Quick Calcs program.

\section{RESULTS}

Total prevalence of Vibrio species from shellfish examined

As tabulated in Table 1, results revealed that the total prevalence of Vibrios pecies isolated from the shellfish examined was 70/410 (17.07\%). The total isolation rates of Vibrio species were $14.63 \%$ from clams, $11.63 \%$ from mussel, and $22.5 \%$ from shrimp. The isolation rate of Vibrio species was highest in Port Said (20.51\%), followed by Ismailia $19.12 \%$ and Suez $6.67 \%$ Governorate.

\section{Prevalence of $V$. parahaemolyticus among} Governorates of Suez Canal area

As tabulated in Table2, results revealed that the total prevalence of $V$. parahaemolyticus isolated from the shellfish examined was 38/410 (9.27\%).

The total isolation rates of $V$. parahaemolyticus, were $(6.01 \%)$ from clams, (4.65\%)from mussels, and $(15 \%)$ from shrimp. The isolation rate of $V$. 
parahaemolyticus was highest in Ismailia Governorate $(12.2 \%)$ followed by Port-said Governorate $(8.94 \%)$ and Suez $(4.44 \%)$. There were no significant differences between the two years of sampling using Chi-square.

Percentage of the prevalence of $V$. parahaemolyticus in relation to Vibrio spp.

As illustrated in Table3, out of 70 isolates of Vibrio species, $38(54.29 \%)$ was confirmed as $V$. parahaemolyticus by microbiological and molecular techniques. The percentage of isolation of $V$. parahaemolyticus to Vibrio species was 24 out of 36 $(66.67 \%)$, where as it was nearly similar in clams $10 / 24$ (41.67\%), and 4/10 (40\%) in mussels. Regarding the location, the highest percentage of V.parahaemolyticus was in Suez $4 / 6$ (66.67\%), followed by Ismailia 20/32 (62.5\%), and Port Said $14 / 34(41.18 \%)$.

Detection of the virulence genes TDH and/or TRH genes among the isolates
As tabulated in Table4, the total detection rate of the TDH gene was $8 / 38(21.05 \%)$, whereas the detection rate of TRH gene was $2 / 38(5.26 \%)$. The positive TRH gene isolate was also TDH gene positive.

The Isolation rate of $V$. parahaemolyticus and distribution of TDH and TRH genes in the water samples

Among 48 water samples, $20(40 \%)$ was Vibrio species positive. Of them, $12(25 \%)$ was identified as V.parahaemolyticus. TDH gene was detected in 2/12(16.67\%) of water $V$. parahaemolyticus samples where as TRH gene was not detected.

Fig. (1) illustrates the Lane $\mathrm{L}$ that indicated the 100 bp DNA ladder, lanes number 1,2, and 3 indicated positive samples yielding an amplified band size of $251 \mathrm{bp}$, Lane $\mathrm{C}+$ and $\mathrm{C}$ - indicated control positive and control negative samples, respectively. And Fig. (2) illustrates the Lane L that indicated the $100 \mathrm{bp}$ DNA ladder, lanes number 1,2 , and 3 indicated positive samples yielding an amplified band size of $367 \mathrm{bp}$, Lane $\mathrm{C}+$ and $\mathrm{C}$ - indicated control positive and control negative samples, respectively.

Table 1: Total prevalence of Vibrio species from shellfish examined.

\begin{tabular}{ccccc}
\hline & \multicolumn{3}{c}{ Geographical location } & \multirow{2}{*}{ Total } \\
\cline { 1 - 4 } Shellfish & Port Said & Ismailia & Suez & \\
\cline { 1 - 4 } Clams & $14 / 56(25 \%)$ & $10 / 80(12.5 \%)$ & $0 / 28(0 \%)$ & $\mathbf{2 4 / 1 6 4}(\mathbf{1 4 . 6 3 \%})$ \\
\hline Mussel & $6 / 24(25 \%)$ & $4 / 28(14.29 \%)$ & $0 / 34(0 \%)$ & $\mathbf{1 0 / 8 6}(\mathbf{1 1 . 6 3 \%})$ \\
\hline Shrimp & $12 / 76(7.89 \%)$ & $18 / 56(32.14 \%)$ & $6 / 28(21.43 \%)$ & $\mathbf{3 6 / 1 6 0}(\mathbf{2 2 . 5 0 \%})$ \\
\hline Total & $\mathbf{3 2 / 1 5 6 ( 2 0 . 5 1 \% )}$ & $\mathbf{3 2 / 1 6 4 ( 1 9 . 1 2 \% )}$ & $\mathbf{6 / 9 0}(\mathbf{6 . 6 7 \%})$ & $\mathbf{7 0 / 4 1 0}(\mathbf{1 7 . 0 7 \%})$ \\
\hline
\end{tabular}

Table 2: Total isolation rate of $V$. parahaemolyticus from shellfish.

\begin{tabular}{|c|c|c|c|c|}
\hline \multirow{2}{*}{ Shellfish } & \multicolumn{3}{|c|}{ Geographical locations } & \multirow{2}{*}{ Total } \\
\hline & Port Said & Ismailia & Suez & \\
\hline Clams & $4 / 56(7.14 \%)$ & $6 / 80(7.5 \%)$ & 0/28(0) & $10 / 164(6.01 \%)$ \\
\hline Mussel & $2 / 24(8.33 \%)$ & $2 / 28(7.14 \%)$ & $0 / 34(0)$ & 4/86 (4.65\%) \\
\hline Shrimp & $8 / 76(10.53 \%)$ & $12 / 56(21.43 \%)$ & $4 / 28(14.29 \%)$ & $24 / 160(15 \%)$ \\
\hline Total & 14/156 (8.94) & 20/164 (12.20\%) & $4 / 90(4.44 \%)$ & $38 / 210(9.27 \%)$ \\
\hline
\end{tabular}

Table 3: Percentage of $V$. parahaemolyticus in relation to Vibrio spp.

\begin{tabular}{ccccc}
\hline \multirow{2}{*}{ Shellfish } & \multicolumn{3}{c}{ Geographical locations } & \multirow{2}{*}{ Total } \\
\cline { 2 - 5 } & Port Said & Ismailia & Suez & \\
\hline Clams & $4 / 14(28.57 \%)$ & $6 / 10(60 \%)$ & $0 / 0(0)$ & $\mathbf{1 0 / 1 6 4 ( 6 . 1 0 \% )}$ \\
\hline Mussel & $2 / 6(33.33 \%)$ & $2 / 4(50 \%)$ & $0 / 0(0)$ & $\mathbf{4 / 8 6 ( 4 . 6 5 \% )}$ \\
\hline Shrimp & $8 / 12(66.67 \%)$ & $12 / 18(66.67 \%)$ & $4 / 6(66.67 \%)$ & $\mathbf{2 4 / 1 6 0 ( 1 5 \% )}$ \\
\hline
\end{tabular}




\begin{tabular}{rllll}
\hline Total & $14 / 32(41.18 \%)$ & $20 / 32(62.5 \%)$ & $4 / 6(66.67 \%)$ & $38 / 410(9.27 \%)$ \\
\hline
\end{tabular}

Table 4: Detection of the virulence genes TDH and/or TRH genes among the $V$. parahaemolyticus isolates.

\begin{tabular}{cccc}
\hline \multirow{2}{*}{ Shellfish } & \multicolumn{3}{c}{ Pathogenicity genes } \\
\cline { 2 - 4 } & TDH & TRH & TDH/TRH \\
\hline Clams & $2 / 10(20 \%)$ & $0 / 10(0 \%)$ & $0(0 \%)$ \\
\hline Mussel & $0 / 4(0 \%)$ & $0 / 4(0 \%)$ & $0(0 \%)$ \\
\hline Shrimp & $6 / 24(25 \%)$ & $2 / 24(8.33 \%)$ & $2 / 24(8.33 \%)$ \\
\hline Total & $\mathbf{8 / 3 8 ( 2 1 . 0 5 \% )}$ & $\mathbf{2 / 3 8}(\mathbf{5 . 2 6} \%)$ & $\mathbf{2 / 2 4}(\mathbf{8 . 3 3 \% )}$ \\
\hline
\end{tabular}

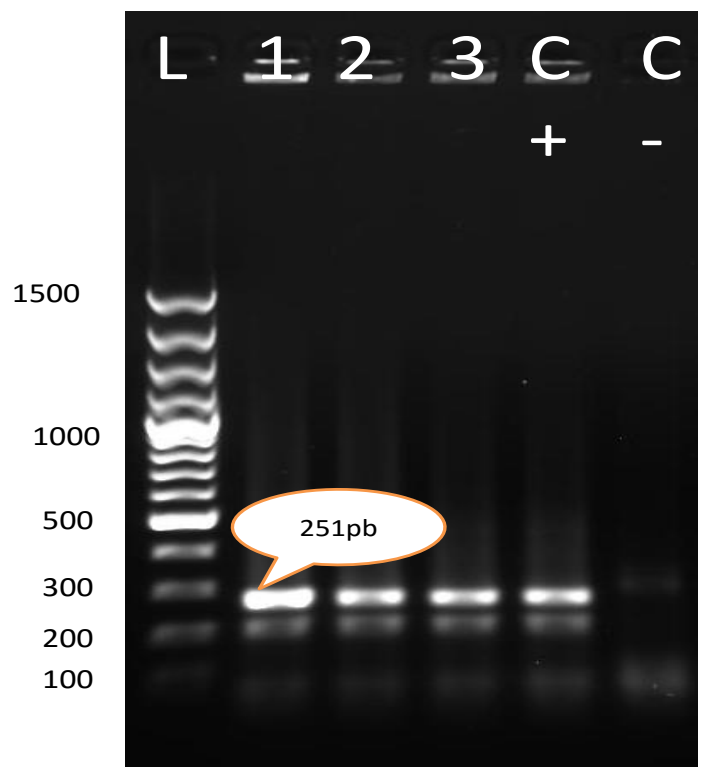

Fig. (1): Agarose gel electrophoresis for PCR analysis of toxR gene in $V$. parahaemolyticus isolated from different shellfish samples. Lane L indicated the $100 \mathrm{bp}$ DNA ladder, lanes number 1,2, and 3 indicated positive samples yielding an amplified band size of $251 \mathrm{bp}$, Lane $\mathrm{C}+$ and $\mathrm{C}$ - indicated control positive and control negative samples.

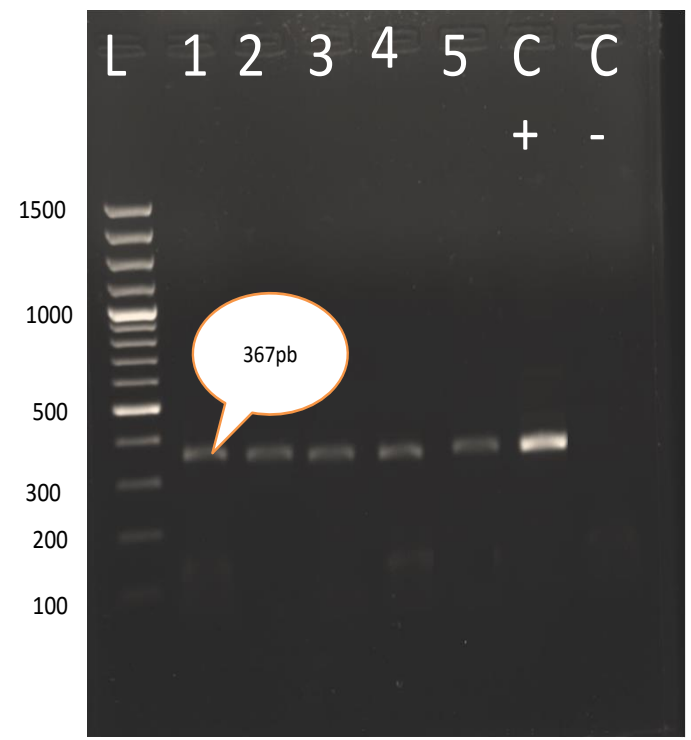

Fig. (2): Agarose gel electrophoresis for PCR analysis of TDH gene (A) and TRH gene (B) in $V$. parahaemolyticus isolated from different shellfish samples. Lane L indicated the 100 bp DNA ladder, lanes 
number 1,2, and 3 indicated positive samples yielding an amplified band size of 367bp, Lane C+ and Cindicated control positive and control negative samples.

\section{DISCUSSION}

V. parahaemolyticus is a zoonotic pathogen and is one of the most significant foodborne pathogens causing gastroenteritis, wound infections, and septicemia (Pinto et al., 2008; Letchumanan et al., 2014). Although $V$. parahaemolyticus is disseminated throughout the world (Yeung and Boor, 2004; Su and Liu, 2007), rare pathogenic variants of $V$. parahaemolytic can cause human gastric infections most of ten from the consumption of raw or improperly handled seafood and wound infections from recreational aquatic activities (McCarter, 1999; Scallan et al., 2011).

In the north Egypt, shellfish is widely eaten in the Suez Canal are as, seafood dishes are preferred for both residents and visitors. The overall high seafood diet, as well as the widespread practice of eating seafood raw, could be associated with a potential risk of food poisoning in that area. Moreover, the Egyptian dietary habits neither including the eating of raw fish nor seafood, but shellfishes could be eaten improperly cooked.

In the present study, the most common shellfish sold in the markets in the Suez Canal areas fish markets were freshly purchased and examined for the hazards of zoonotic Vibrio spp. contaminations. The overall prevalence of Vibrio species was $22.5 \%$. These results were lower than that reported by Eissa et al. (2011) in Egypt (31.1\%). Another study revealed that the total prevalence of Vibrio spp. in the Northeast of Egypt was $57.3 \%$ in shrimp, $54 \%$ in oysters (Merwad et al., 2011). Incidence was $43.4 \%$ in shrimp in China (Xu et al., 2016). The high prevalence of Vibrio species isolation from shellfish that was detected in the study area could be attributed to the collection of samples during the hot season. It has been reported that, $V$. parahaemolyticus may be detected year-round in locations where water temperatures do not drop below $15^{\circ} \mathrm{C}$ with the number of organisms detected in water, sediment and oysters increasing as water temperatures rise and the risk of exposure to an infectious dose of pathogens increases ( $\mathrm{Su}$ and $\mathrm{Lu}$, 2007; Johnson et al., 2010; Eissa et al., 2011). On the other hand, oysters may have a concentration of $V$. parahaemolyticus up to 100 -fold higher than surrounding waters due to filter feeding particularly in the summer season which increases the chances of infection (Morris 2003). However, temperature and total abundance do not fully explain contamination rates with V.parahaemolyticus as some infections occur when water temperatures and abundance of total V.parahaemolyticus are low (Zimmerman et al., 2007).
Results of the current study revealed a high prevalence of V.parahaemolyticus in shellfish in Suez Canal areas. This result was lower matched with another study conduct in the same study area which were $22.5 \%$ in shrimps and $16.7 \%$ in shellfish samples (Abd-Elghany and Sallam, 2013). Higher incidences of $V$. parahaemolyticus in shellfish were also reported in many studies. The incidence of $V$. parahaemolyticus in shellfish was $36.2 \%$ in China (Xu et al., 2016). The high detection rate of $V$. parahaemolyticus in shrimp detected in the present study $9.27 \%$ was higher compared to $2.6 \%$ of another study (Merwad et al., 2011). Controversy, Eissa et al. (2011) detected high incidences of $V$. parahemolyticus in marine shrimp in Suez-bay $(31.1 \%)$.

In this study, V. parahaemolyticus was isolated from water samples collected from the study area. Similarly, Hassanin, (2007) identified 40\% V. parahaemolyticus in water samples of fishing farm in Abu-Kir, Egypt. The overall prevalence of Vibrio spp. in water samples from Suez Canal was 25\% (5 out of 20) (Abdel-Ghany and Sallam, 2013). Another study showed contamination rates of marine water in Egypt with $V$. parahaemolyticus (25\%) (Merwad et al., 2011). In contrary, lower incidences of $V$. parahaemolyticus in water were noticed in other studies. Mohamed et al. (2000) reported an isolation rate of $6.25 \%$ from River Nile tributaries at Damietta Province, Egypt. On the contrary, these results disagreed with Merwad et al. (2011), who did not detect $V$. parahaemolyticus in the same study area. It has been reported that $V$. parahaemolyticus levelsin water are strongly correlated with turbidity during summer (Zimmerman et al., 2007).

It is worthmentioned that these results are not accepted concerning the Egyptian standard (ES,2005), as it should be free from $V$. parahaemolyticus. Climate global change can play animportant role in the dissemination of pathogenic microorganisms in the marine environment (Letchumanan et al., 2015). The difference in the incidence of $V$. parahaemolyticus among samples from both sampling sites could possibly be contributed by the original source from which the shellfish were collected, post-harvest practices and hygiene standards applied during handling, transportation, and storage of seafood products. Moreover, the lack of hygiene, improper handling, cross-contamination and difference in storage temperature could be the possible cause of variation in $V$. parahaemolyticus incidences in samples from the supermarket (Yang et al., 2008).

Concerning the zoonotic aspect, the hazardous pathogenic Vibrio causes life-threatening foodborne 
infections and poses a considerable public health threat as agents of sporadic and epidemic human infections to berepresented an important microbial group in the field of food safety (Rippey, 1994). $V$. parahaemolyticus was identified in $4 \%$ in diarrheicpatients in Egypt (Merwad et al., 2011; Abdel-Ghany and Sallam, 2013). A lower percentage of $2.4 \%$ in Damietta province, Egypt was cited (Mohamed et al., 2000).

To assess the actual risk to human health posedby the presence of $V$. parahaemolyticus in seafood, the incidence of pathogenic strains need to be identified by detection of the toxigenic genes responsible for causing diseases in humans. Strains of $V$. parahaemolyticus carrying $t d h$ and/or trh are considered pathogenic (Turner et al., 2013). Previous investigations revealed that $1-2 \%$ of the environmental strains harbored the $T D H$ and $T R H$ genes under natural conditions (Alam et al., 2002; Hervio-Heath et al., 2002; Abd Elghany and Sallam, 2013).

TDH gene has been recognized as a primary virulence factor in pathogenic $V$. parahaemolyticus (Okuda et al., 1997; Pinto et al., 2008). TDH geneis currently used as pathogenicity marker since most clinical isolates of $V$. parahaemolyticus possess this gene (Bej et al., 1999; Nordstrom et al., 2007). Generally, 0.2 to $3 \%$ of environmental $V$. parahaemolyticus isolates are potentially pathogenic based on the presence of TDH gene (Nordstrom et al., 2007).

In the present study, TDH and TRH genes were detected (Fig.1), these results were higher than that detected by Abd-Elghany and Sallam, (2013) who found that $3 / 120(2.5 \%)$ seafood samples were positive for one or bothtdh and trh virulent. In a previous study conducted in Italy, one and three strains were positive for tdh and trh genes, respectively out of $35 \mathrm{~V}$. parahaemolyticus isolates from mussels (Ottaviani et al., 2005). TDH+ V.parahaemolyticus was detected in $3.4 \%$ of oysters from India (Raghunath et al., 2015) and 3.4\% of oysters from New Zealand (Kirs et al., 2011). Another study in Malaysia identified higher trhpositive $6.5 \%(13 / 200)$ while none was $t d h$-positive. Conversely, higher incidences of virulent $V$. parahaemolyticus isolates from seafood were identified in the USA by Bej et al. (1999) who could detect tdh and trh genes in $32.56 \%$ (14/43) and $23.3 \%$ (10/43), respectively in examined seafood isolates. Likewise, Terzi et al. (2009) in Turkey confirmed that $24(75 \%)$ out of the $32 \mathrm{~V}$. parahaemolyticus isolated from mussel were tdh and trhgenes positive. Much higher incidences of 85\% (17/20) of shellfish samples tested in Chile were positive for tdh (Fuenzalida et al., 2007). Additionally, both tdh and trh genes were detected in $44 \%(12 / 27)$ and 52\% $(14 / 27)$, respectively in oyster samples tested in
Alaska (Nordstrom et al., 2007). The percent $44-56 \%$ of Eastern oysters from Mexico (Zimmerman et al., 2007). In total, $145 \mathrm{~V}$. parahaemolyticus isolates were confirmed and tested for the presence of trh and tdh. None of the isolates possessed these genes ( $\mathrm{Xu}$ et al., 2016). V. parahaemolyticus, of the 38/71 (53.5\%) isolates were positive for the trh virulence gene and $71(100 \%)$ were negative for the TDH gene (Kang et $a l$. , 2016). The differences in the frequency of the TDH and/or TRH pathogenicity genes may depend on the location, sample source, and detection methods (Alam et al., 2002; Cook et al., 2002; Hervio-Heath et al., 2002). There fore, continued monitoring of both the prevalence of $V$. parahaemolyticus, with surveys expanded to the national level, is important to ensure shellfish safety.

\section{CONCLUSIONS AND RECOMMENDATIONS}

In conclusion, the results of this study constitute an indicator of $V$. parahaemolyticus contamination of a variety of seafood. Although virulent strains of $V$. parahaemolyticus can cause distinct diseases, including wound infections, septicemia, or more commonly acute gastroenteritis, pathogenicity is strongly correlated with two well-characterized hemolysins, the thermostable direct hemolysin (TDH) and the TDH-related hemolysin (TRH). Genes responsible for producing these toxins were detected in this study. The presence of these pathogenic organisms in seafood and water could pose a serious threat and hazard to susceptible people through consumption of raw or undercooked seafood, especially shellfish Thus, it is recommended that: Monitoring of harvesting areas for the prevalence of $V$. parahaemolyticus, with continued surveys, expanded to the national level, considering various locations, sample source, and detection methods is important to ensure shellfish safety. In addition, postharvest practices and hygiene standards applied during handling, transportation, and storage of seafood products including measures for preventing cross-contamination. Seafood should be adequately cooked before consumption to identify and implement proper public health measures for the control and prevention of diseases caused by pathogenic $V$. parahaemolyticus.

\section{REFERENCES}

Abd-Elghany, S.M. and Sallam, K.I. (2013): Occurrence and molecular identification of Vibrioparahaemolyticus inretailshellfish in Mansoura. Egypt. Food Control 33: 399405.doi:10.1016/j.foodcont.2013.03.024.

Adams, M.R. and Moss, M.O. (2008): Bacterial agents of food borne illness In Food

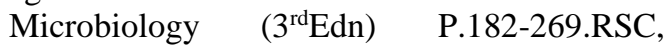
Cambridge United Kingdom.

Alam, M.J.; Tomochika, K.I.; Miyoshi, S.I. and Shinoda, S. (2002): Environmental 
investigation of potentially pathogenic Vibrio parahaemolyticus in the Seto-Inland Sea, Japan. FEMS MicrobiologyLetters 208:8387.doi:10.1111/j.1574- 6968. 2002.tb11064.x.

Bej, A.K.; Patterson, D.P.; Brasher, C.W.; Vickery, M.C.; Jones, D.D. and Kaysner, C.A. (1999): Detection of total and hemolysin-producing Vibrio parahaemolyticus in shellfish using multiplex PCR amplification of $\mathrm{tl}$, tdh and trh. Journal of Microbiological Methods 36: 215225.

Burge, C.A.; Mark Eakin, C.; Friedman C.S.; Froelich, B.; Hershberger, P.K.; Hofmann E.E.; Petes, L.E.; Prager, K.C.; Weil, E.; Willis, B.L.; Ford, S.E. and Harvell, C.D. (2014): Climate change influences on marine infectious diseases: implications for management and society. Annual Review of Marine Science 6: 249-277. doi:10.1146/annurev-marine-010213-135029.

Ceccarelli, D.; Hasan, N.A.; Huq, A. and Colwell, R.R. (2013): Distribution and dynamics of epidemic and pandemic Vibrio parahaemolyticus virulence factors. Frontiers in Cellular and Infection Microbiology 3, 97. http://doi.org/10.3389/fcimb.2013.00097

Cook, D.W.; O’Leary, P.; Hunsucker, J.C.; Sloan, E.M.; Bowers, J.C.; Blodgett R.J. and DePaola, A. (2002): Vibrio vulnificus and Vibrio parahaemolyticus in US retail shell oysters: a national survey from June 1998 to July 1999. Journal of Food Protection 65:7987.

Cruz, C.D.; Hedderley, D. and Fletcher, G.C. (2015): Long-term study of Vibrio parahaemolyticus prevalence and distribution in New Zealand shellfish. Applied Environmental Microbiology 81(7):2320-7.

Egyptian organization for standardization and Quality control (ES) (2005): Egyptian standard No.ss9. for frozen fish, part 2: fish portion.

Eissa, I.A.M.; Derwa, H.I.M. and Abd-Elrehim, A.A.M. (2011): Epizootiological studies on vibriosis in marine shrimp Penaeusjaponicus in Suez-Bay. Suez Canal Veterinary Medicine Journal, XVI (2): 85-86 2011.

Esteves, K.; Hervio-Heath, D.; Mosser, T.; Rodier, C.; Tournoud, M.G.; Jumas-Bilak, E. and Colwell, R.R. (2015): Monfort P. Rapid proliferation of Vibrio parahaemolyticus, Vibrio vulnificus, and Vibrio cholerae during freshwater flash floods in French Mediterranean Coastal Lagoons. Applied Environmental Microbiology81 (21):7600-9.

Fuenzalida, L.; Armijo, L.; Zabala, B.; Hernandez, C.; Rioseco, M.L.; Riquelme, C. and Espejo, R.T. (2007): Vibrio parahaemolyticus strains isolatedduring investigation of the summer 2006 seafood related diarrhea outbreaks in two regions of Chile. International Journal of Food Microbiology, 117: 270-275.

Hassanin, M.E. (2007): Studies on some problems facing cultured shrimp in Egypt. Ph. D. degree in Vet. Medical Science (Fish Diseases and Management), Faculty of Vet. Medicine, Zagazig University.

Hervio-Heath, D.; Colwell, R.R.; Derrien, A.; RobertPillot, A.; Fournier, J.M. and Pommepuy, M. (2002): Occurrence of pathogenic vibrios in coastal areas of France. Journal of Applied Microbiology 92, 1123-1135.doi:10.1046/j. 1365- 2672.2002.01663.

Johnson, C.N.; Flowers, A.R.; Noriea, N.F.; Zimmerman, A.M.; Bowers, J.C.; DePaola, A. and Grimes, D.J. (2010): Relationships between environmental factors and pathogenic vibrios in the Northern Gulf of Mexico. Applied and Environmental Microbiology 76(21), 7076-7084.http://doi. org/10.1128/AEM.00697-10

Kang, C.H.; Shin, Y.; Kim, W.; Kim, Y.; Song, K.; Oh, E.G.; Kim, S.; Yu, H. and So, J.S. (2016): Prevalenceand antimicrobial susceptibility of Vibrio parahaemolyticus isolated from oysters in Korea. Environmental Science and Pollution Research International 23(1):918-26. doi: 10.1007/s11356-015-5650-9. Pub Med PMID: 26511256.

Kaysner, C.A. and DePaola, A.Jr. (2004): Bacteriological analytical Manual, (2004); chapter 9 (vibrio).

Kim, S.H.; Sin, Y.M.; Lee, M.J.; Shin, P.K.; Kim, M.G.; Cho, J.S.; Lee, C.H.; Lee, Y.J. and Chae K.R. (2005): Isolation of major foodborne pathogenic bacteria from ready-to-eat seafoods and its reduction strategy. Journal of Life Science 15:941-947.

Kirs, M.; Depaola, A.; Fyfe, R.; Jones, J.L.; Krantz, J.; Laanen, A.V.; Cotton, D. and Castle, M. (2011): A survey of oysters (Crassostreagigas) in NewZealand for Vibrio parahaemolyticus and Vibrio vulnificus. International Journal of Food Microbiology, 147: 149-153.

Lee, J.; Jung, D.; Eom, S.; Oh, S.; Kim, Y.; Kwak, H. and Kim, Y. (2008): Occurrence of Vibrio parahaemolyticus in oysters from Korean retail outlets. Food Control 19: 990-994. http://dx.doi.org/10.1016/j.foodcont.2007.10.0 06.

Letchumanan, V.; Chan, K.G. and Lee, L.H. (2014): Vibrio parahaemolyticus: a review on the pathogenesis, prevalence, and advance molecular identification techniques. Frontiers in Microbiology, 5:705. doi:10.3389/fmicb. 2014.00705.

Letchumanan, V.; Pusparajah, P.; Tan, L.T.; Yin, W.F.; Lee, L.H. and Chan, K.G. (2015): Occurrence andAntibiotic Resistance of Vibrio parahaemolyticus from Shellfish in Selangor, 
Malaysia. Frontiers in Microbiology 15(6):1417. doi: 10.3389/fmicb.2015.01417. PubMed PMID: 26697003; PubMed Central PMCID: PMC4678184.

Merwad, A.M.A.; Amin, M.A.M.; El-Ghareeb, W.R. and Taisir, S.M. (2011): Occurrence of some zoonotic Vibrios in shellfish and diarrheic patients with regard to tdh Gene in Vibrio Parahaemolyticus. 364 Journal of American Science; 7 (9): 449-459

McCarter, L. (1999): The multiple identities of Vibrio parahaemolyticus, Journal of Molecular Microbiology and Biotechnology 1: 51e57.1.

Mohamed, A.A.; Zaki, M.S.A. and Abd El-Maksoud, S.A. (2000): Epidemiological study on fish borne Vibrio species with special reference to their public health importance. Zagazig Veterinary Journal 28 (2): 97-106.

Morris, J.G.Jr. (2003): Cholera and other types of vibriosis: a story of human pandemics and oysters on the half shell. Clinical and Infectious Diseases 37 (2):272-280.

Nair, G.B.; Ramamurthy, T.; Bhattacharya, S.K.; Dutta, B.; Takeda, Y. Sack, D.A. (2007): Global dissemination of Vibrio parahaemolyticus serotype O3:K6 and its serovariants, Clinical Microbiology Reviews 20 39-48.

Nishibuchi, M. and Kaper, J.B. (1995): Thermostable direct hemolysin gene of Vibrio parahaemolyticus: a virulence gene acquired by a marine bacterium. Infection and Immunity 63: 2093-2099.

Nordstrom, J.L.; Vickery, M.C.; Blackstone, G.M.; Murray, S.L. and DePaola, A. (2007): Development of a multiplex real-time PCR assay with an internal amplificationcontrol for the detection of total and pathogenic Vibrio parahaemolyticus bacteria in oysters. Applied and Environmental Microbiology 73: 58405847.

Okuda, J.; Ishibashi, M.; Hayakawa, E.; Nishino, T.; Takeda, Y.; Mukhopadhyay, A.K.; Garg, S.; Bhattacharya, S.K.; Nair, G.B. and Nishibuchi, M. (1997): Emergence of a unique O3:K6 clone of Vibrio parahaemolyticus in Calcutta, India, and isolation of strains from the same clonal group from southeast Asian travelers arriving in Japan. Journal of Clinical Microbiology 35: 3150-3155.

Ottaviani, D.; Santarelli, S.; Bacchiocchi, S.; Masini, L.; Ghittino, C. and Bacchiocchi, I. (2005): Presence of pathogenic Vibrio parahaemolyticus strains in mussels from the Adriatic Sea, Italy. Food Microbiology 22, 585-590.

Pinto, A.D.; Circcarese, G.; Corato, R.D.; Novello, L. and Terio, V. (2008): Detection of pathogenic Vibrio parahaemolyticus in Southern Italianshellfish. Food Control 19: 1037-1041.
Potasman, I.; Paz, A. and Odeh, M. (2002): Infectious outbreaks associated with bivalve shellfish consumption: a worldwide perspective. Clinical and Infectious Diseases 35, 921-928. doi: 10.1086/342330.

Raghunath, P. (2015): Roles of termostable direct hemolysin (TDH) and TDH-related hemolysin (TRH) in Vibrio parahaemolyticus. Frontiers in Microbiology5: 805. doi: 10.3389/fmicb. 2014.00805.

Rippey, S.R. (1994): Infectious diseases associated with molluscan shellfish consumption. Clinical Microbiological Reviews 7: 419-425.

Scallan, E.; Hoekstra, R.M.; Angulo, F.J.; Tauxe, R.V.; Widdowson, M.A.; Roy, S.L.; Jones, J.L. and Griffin, P. M.(2011). Foodborne illness acquired in the United States-majorpathogens. Emerging Infectious Diseases 17 (1): 7-15. doi:10.3201/eid1701.P11101.

Su, Y.C. and Liu, C. (2007): Vibrio parahaemolyticus: a concern of seafood safety. Food Microbiology 24 549e558.

Tada, J.; Ohashi, T.; Nishimura, N.; Shirasaki, Y.; Ozaki, H.; Fukushima, S.; Takano, J.; Nishibuchi, M. and Takeda, Y. (1992): Detection of the thermostable direct hemolysin gene (tdh) and the thermostable direct hemolysin-related hemolysin gene (trh) of Vibrio parahaemolyticus by polymerase chain reaction. Molecular and Cellular Probes 6:477-487.

Terzi, G.; Büyüktanir, O. and Yurdusev, N. (2009): Detection of the tdh and trh genes in Vibrio parahaemolyticus isolates in fish and mussels from Middle Black SeaCoast of Turkey. Letters in Applied Microbiology, 49: 757-763.

Tunung, R.; Jeyaletchumi, P.; Noorlis, A.; Tang, Y.H.; Sandra, A.; Ghazali, F.M.; Noranizan, M.A.; Lesley, M.B.; Haresh, K.K.; Nakaguchi, Y.; Nishibuchi, M. and Son, R. (2012): Biosafety of Vibrio parahaemolyticus from vegetables based on antimicrobial sensitivity and RAPD profiling. International Food Research Journal 19: 467-474

Turner, J.W.; Paranjpye, R.N.; Landis, E.D.; Biryukov, S.V.; Gonzalez-Escalona, N.; Nilsson, W.B. and Strom, M.S. (2013): Population structure of clinical and environmental Vibrio parahaemolyticus from the Pacific North west coast of the United States. PLoSONE 8:55726. doi:10.1371/ journal.pone. 0055726 .

$X u, X$.; Cheng, J.; Wu, Q.; Zhang, J. andXie, T. (2016): Prevalence, characterization, and antibiotic susceptibility of Vibrio parahaemolyticus isolated from retail aquatic products in North China. BMC Microbiology 16:32. doi:10.1186/s12866-016-0650-6.

Yamamoto, A.; Iwahori, J.; Vuddhakul, $V$. ; Charernjiratragul, W.; Vose, D.; Osaka, K.; Shigematsu, M.; Toyofuku, H.; Yamamoto, S.; 
Nishibuchi, M. and Kasuga, F. (2008): Quantitative modeling for risk assessment of Vibrio parahaemolyticus in bloody clams insouthern Thailand. International Journal of Food Microbiology124(1): 70-8. doi:10. 1016/j.ijfoodmicro.2008.02.021. Pub Med PMID: 18405992.

Yang, Z.Q.; Jiao, X.A.; Zhou, X.H.; Cao, G.X.; Fang, W.M. and Gu, R.X. (2008): Isolation and molecular characterization of Vibrio parahaemolyticus from fresh, low temperature preserved, dried and salted seafood products in two coastal areas of eastern China.
International Journal of Food Microbiology, 125(3):279-85

Yeung, P.S. and Boor, K.J. (2004): Epidemiology, pathogenesis, and prevention of foodborne Vibrio parahaemolyticus infections, Foodborne Pathogen and Disease 1:74-88.

Zimmerman, A.; Depaola, A.; Bowers, J.C.; Krantz, J.A.; Nordstrom, J.L.; Johnson, C.N. and Grimes, D.J. (2007): Variability of total and pathogenic Vibrio parahaemolyticus densities in northern Gulf of Mexico water and oysters. Applied Environmental Microbiology 73: 7589-7596.doi:10.1128/AEM.01700-07.

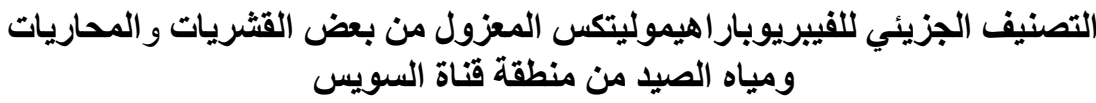

أحد بيوسف ، أمانحي فرج حما ، ايهاب هلال

E-mail:dramani_egac@yahoo.com Assiut University web-site:www.aun.edu.eg

يعتبر الفيبريوبار اهيموليتكس احد اسباب التسمم الغذائي من الاغذية البحرية. الهدف الرئيسي من هذه الدراسة تحديد مدى تواجد

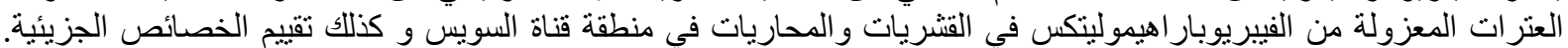

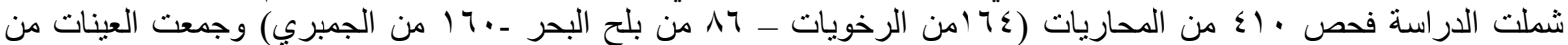

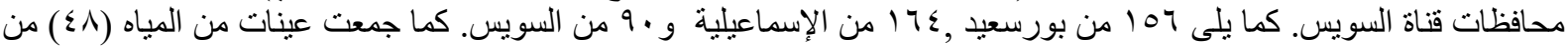

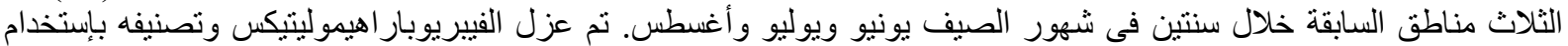

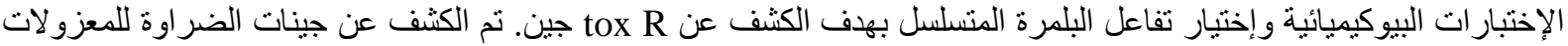

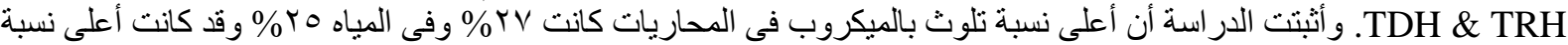

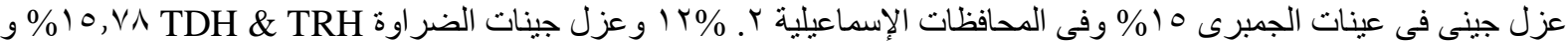

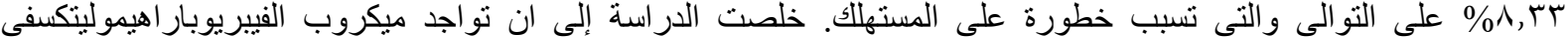

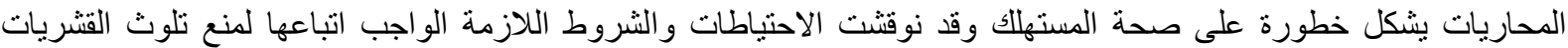
و المحاريات بمثل هذا الميكروب وكذللك لتجنب الإصابة بهذا النوع من التسمع الغذائي. 